\title{
“ANÁLISE ECONÔMICA DA LIMITAÇÃO PROBATÓRIA NO SISTEMA DOS
} JUIZADOS ESPECIAIS CÍVEIS"

\author{
“A LAW AND ECONOMICS APPROACH TO THE LEGAL LIMITATION OF EVIDENCE \\ PRESENTATION IN SMALL CLAIMS COURTS"
}

Eduardo Calvert*

Resumo:

O presente estudo tem o objetivo de trazer algumas considerações iniciais acerca da Análise Econômica do Direito e introduzir o pensamento econômico à análise de algumas questões relacionadas à produção de provas no processo civil para, com base em premissas estabelecidas por meio da análise econômica, verificar a limitação probatória imposta pela Lei n. 9.099/95 aos procedimentos submetidos ao sistema dos juizados especiais cíveis.

Pretende-se demonstrar que há uma racionalidade econômica na limitação probatória nos processos da competência dos juizados especiais cíveis, para ao fim concluir, contrariamente ao entendimento majoritário adotado pela doutrina e jurisprudência, que mesmo quando se identifique a utilidade da produção de prova pericial nos processos submetidos ao juizado especial em razão do valor da causa, estes deverão ser julgados com base nas provas permitidas pelo procedimento, sem que a complexidade da questão probatória importe na incompetência da justiça especial.

Palavras-chave: Análise econômica do direito. Processo civil. Produção probatória. Juizados especiais cíveis.

\begin{abstract}
:
The scope of this paper is to bring initial considerations regarding the Law and Economics approach and to adopt the economic analysis to investigate the presentation of evidence in judicial civil procedure, focusing our analysis on the legal limitation of evidence presentation imposed to especial procedure applied in small claims courts.

We intend to demonstrate the economic rationality that explains the legal limitation of evidence presentation in small claims courts to conclude, against majority of authors' opinions and judicial understanding, that the judgment must be carried on in small claims courts based only on the evidence permitted by the special procedure, notwithstanding the utility of the presentation of complex evidence.
\end{abstract}

Keywords: Law and economics. Civil procedure. Evidence presentation. Small claims courts.

\footnotetext{
* Juiz de Direito. Bacharel em Direito pela Faculdade de Direito da Universidade de São Paulo. Mestrando em Direito Processual Civil na Faculdade de Direito da Universidade de São Paulo.
} 
1. Análise econômica da limitação probatória no sistema dos Juizados Especiais Cíveis

\title{
1.1. Introdução
}

A aplicação de conceitos e métodos da Economia nas análises de questões jurídicas, para aqueles que não estão familiarizados com a Análise Econômica do Direito (doravante, “AED”), pode levar a um estranhamento inicial, uma ideia de contradição ou de impossibilidade. Como explica Bruno Salama (2014, p. 29)

essa impossibilidade decorre das diferenças de método entre o Direito e a Economia. Enquanto o Direito é exclusivamente verbal, a Economia é verbal e matemática. Enquanto o procedimento da análise jurídica é marcadamente hermenêutico, o procedimento da análise econômica é fortemente empírico. Enquanto a aspiração última do Direito é a Justiça, a aspiração última da Economia é a ciência. Finalmente, e mais importante que tudo, enquanto uma crítica jurídica se dá a partir da legalidade, uma crítica econômica se dá a partir do custo.

No entanto, conforme veremos a seguir, o argumento econômico está amplamente presente nas normas jurídicas em seus mais variados ramos.

Ao apresentar seu Curso de Economia inteiramente direcionado àqueles que se dedicam ao Direito, o Professor Fábio Nusdeo (2013, p. 21) lembra

\begin{abstract}
aos que se iniciam não existir propriamente uma relação entre as duas matérias - o Direito e a Economia. Elas, na realidade, se imbricam e se integram para formar um único campo de estudo, bastando lembrar que aproximadamente 90\% do conteúdo do Código Civil é constituído por dispositivos de cunho econômico: contratos, regime de bens no matrimônio e nas sucessões, a propriedade, as obrigações, todos têm subjacentes a si uma realidade econômica, por implicarem situações ou operações onde se cogita de bens escassos e, portanto, dotados de valor.
\end{abstract}

O termo "economia”, em sua origem, pode ser traduzido como "organização de uma casa" ou "aquele que administra um lar". ${ }^{1}$ Ao apresentar o indivíduo como alguém que age de forma racional com a finalidade de aumentar o seu bem-estar, a Economia

\footnotetext{
A palavra economia tem origem etimológica proveniente da expressão grega "oikos+nomos", onde "oikos" ou "oikia", no sentido mais amplo, quer dizer "casa" e "nomos" quer dizer "norma" ou "normatização", no sentido de "dar ordem", "organizar", "administrar", "prover" (NUSDEO, 2013, p. 31). Segundo N. Gregory Mankiw (2007, p. 3), "a palavra economia vem do termo grego e pode ser entendida como 'aquele que administra um lar'. A princípio, essa origem pode parecer estranha. Mas, na verdade, os lares e as economias têm muito em comum".
} 
organiza e teoriza conceitos que se mostram, em última análise, familiares a qualquer pessoa e decorrentes da avaliação lógica de situações cotidianas.

O presente estudo tem o objetivo de introduzir o pensamento econômico à análise de algumas questões relacionadas à produção de provas no processo, sem a pretensão de construir um modelo econômico ou de ir além do mero apontamento de uma forma diferente de se analisar os institutos processuais e fomentar a discussão.

Pretende-se demonstrar que há uma racionalidade econômica na limitação probatória nos processos da competência dos juizados especiais cíveis (doravante, “JEC") submetidos ao procedimento instituído pela Lei n. 9.099/95, para ao fim concluir, contrariamente ao entendimento majoritário adotado pela prática forense, ${ }^{2}$ que mesmo quando se identifique a utilidade da produção de prova pericial nos processos submetidos ao JEC em razão do valor da causa, estes deverão ser julgados com base nas provas permitidas pelo procedimento, sem que a complexidade da questão probatória importe na incompetência da justiça especial.

\section{A Análise Econômica do Direito e sua Relação com o Processo Civil}

2.1. Breve introdução à AED

"Law and Economics", ou AED, consiste na aplicação ao Direito de aportes teóricos oriundos das ciências econômicas, viabilizando a compreensão do ordenamento jurídico como estrutura de incentivos ao comportamento humano e o esclarecimento das consequências dos comandos legais e judiciais, assumindo relevância no próprio processo de elaboração desses comandos. Consagra-se a rejeição da ilusão de que a técnica jurídica, empregada de modo isolado, é suficiente para a solução dos conflitos sociais, reconhecendo-se a relevância dos aportes teóricos de outras áreas do saber para o desenvolvimento de respostas mais completas e vinculadas à realidade social.

A AED procura soluções para problemas jurídicos com a utilização dos critérios de eficiência adotados pela ciência econômica, obtendo resultados mais vantajosos para a comunidade com o envolvimento de custos sociais menos gravosos, objetivo supremo da ciência jurídica.

Ela surge para tentar suprir a ausência de métodos científicos para avaliar, prever e, até mesmo, guiar a decisão de um juiz ou de um agente público, a partir da aplicação de técnicas empregadas na ciência econômica, e não apenas na intuição do agente.

Conforme se depreende do enunciado 54 do Fórum Nacional de Juizados Especiais ("FONAJE"): “A menor complexidade da causa para a fixação da competência é aferida pelo objeto da prova e não em face do direito material". 
A AED pode ser apontada como uma escola jurídica "pós-positivista". Este aspecto de análise vai ao encontro das lições do Professor Boaventura de Sousa Santos (2008, p. 76), para quem uma das características mais marcantes do paradigma jurídico emergente consiste na adoção da ideia de que os temas objeto da investigação científica não são, na pós-modernidade, examinados de maneira estanque por cada disciplina, mas a partir da multiplicidade de contribuições oriundas de vários campos do conhecimento:

A fragmentação pós-moderna não é disciplinar e sim temática. Os temas são galerias por onde os conhecimentos progridem ao encontro uns dos outros. Ao contrário do que se sucede no paradigma actual, o conhecimento avança na medida em que o seu objeto se amplia, ampliação que, como a da árvore, procede pela diferenciação e pelo alastramento das raízes em busca de novas e mais variadas interfaces.

Não obstante o desenvolvimento de escolas jurídicas ligadas à Economia tenha raízes no século XIX, com manifestações doutrinárias mais robustas no início do século XX na Alemanha, ${ }^{3}$ ela somente surgiu em seu formato atual a partir da década de 40 do século XX, na Universidade de Chicago. Em suas primeiras décadas, os conceitos econômicos eram aplicados especialmente em direito concorrencial, sendo somente a partir da década de 60 que seus estudiosos se dedicaram a outras áreas jurídicas, como responsabilidade civil, propriedade e direito penal.

\subsection{A aplicação da AED no processo civil}

A aplicação da AED ao processo focará seus esforços em 2 (dois) aspectos: (i) os custos do litígio, entendidos como os custos de manutenção da estrutura judiciária e os custos ordinários expendidos pelas partes para início e desenvolvimento do processo judicial, incluindo-se honorários de advogado, emolumentos e custas judiciais, honorários de peritos e outros gastos com a produção probatória (dentre os custos do processo, o tempo pode também ser considerado); e (ii) os custos do erro judicial, entendidos como

Relata o Professor Fábio Nusdeo (2013, p. 407) que no ano de 1912, na Cidade alemã de Jena, reuniu-se em congresso um grupo seleto de juristas teutos, tendo à frente Justus Wilhelm Hedemann, com a intenção de discutir a recente evolução do direito em face das sensíveis mudanças atravessadas pela sociedade alemã da época, após a unificação e a rápida industrialização e urbanização do país. Conta que "o dito congresso de Jena, como já visto, concluiu-se com o lançamento de um manifesto ao qual se deu o significativo título de 'an das recht der gegenwart', ou seja, 'por um Direito Moderno', também conhecido como Manifesto de Jena ou Manifesto por um novo Direito. Um ano antes, havia-se fundado naquela cidade uma sociedade chamada Direito e Economia (Recht und Wirtschaft) cujas atividades foram obnubiladas pelos eventos bélicos de 1914-1918, ao cabo dos quais um intenso labor de pesquisa e de elaboração doutrinária levou a se fixar, sempre na Alemanha, o conceito de um Direito Econômico que, pouco depois, chegaria à Itália, França e demais países do continente". 
as consequências da falha na realização do direito material, especialmente a redução do efeito dissuasório da decisão e o desincentivo às atividades econômicas. ${ }^{4}$

AAED reconhece a existência de uma clara escolha (ou "tradeoff", segundo o termo utilizado pelos economistas ${ }^{5}$ ) entre os custos do procedimento e os custos do erro: quanto mais simples e sumários os procedimentos são, menores os seus custos; por outro lado, maiores as chances de ocorrer um erro no julgamento em razão da deficiência da apreensão dos fatos relevantes ao julgamento.

Geoffrey P. Miller (1997, p. 905-918) ilustra bem essa relação permanente de troca entre custos e acuidade:

To illustrate these general points more concretely, consider the basic question of the line between substance and procedure. The law-and-economic analysis of litigations sees a trade-off between two costs: the costs of the procedure in question, and the costs of error. The existence of such a trade-off is quite clear-cut. As the procedures involved in resolving a dispute become more and more summary, the probability that the finder of fact or law will make an error will usually increase. At the limiting case, we could imagine a judge simply tossing a coin; this would be an extraordinarily efficient means of dispute resolution, but it would be unlikely to achieve accurate results. On the other hand, we can imagine a system that erred in the other direction: all evidence would be admitted; all witnesses would be subject to examination, cross-examination, and impeachment; evidence would not be excluded as repetitive; and so on. Such a system of dispute resolution is perhaps more likely to achieve substantively 'correct' result than a less elaborate one (although as procedures become too elaborate they may become counterproductive), but it does so at increased cost.

From the standpoint of welfare economics, the efficient result (holding certain other factors equal) would be a system that minimized the sum of the two costs - the costs of erroneous results (inaccuracy), on the one hand, and the costs of the applicable procedures, on the other.

$4 \quad$ "The economic analysis of procedure reduces most issues to direct costs and error costs. Direct costs are ordinary litigation costs. Error costs are the reduction in deterrence and the increase in chilling that result from inaccurate adjudication. The goal of procedure is the minimization of the sum of direct and error costs" (KLERMAN, 2015, p. 2).

5 "Em economia, tradeoff é uma expressão que define uma situação de escolha conflitante, isto é, quando uma ação econômica que visa à resolução de determinado problema acarreta, inevitavelmente, outros. Por exemplo, em determinadas circunstâncias, a redução da taxa de desemprego apenas poderá ser obtida com o aumento da taxa de inflação, existindo, portanto, um tradeoff entre inflação e desemprego" (MANKIW, 2007, p. 4). 
Ou seja, muito embora de um ponto de vista ideal a produção de provas (ou a busca de informação) no procedimento judicial seja benéfica por permitir um julgamento mais acertado, é virtualmente impossível pensar num sistema que tenha a capacidade de excluir completamente a ocorrência de erros:

To understand direct costs and error costs, first consider a perfect legal system. Such a system would cost nothing and implement substantive law with 100\% accuracy. Obviously, such an ideal system is impossible. All legal systems deviate from the ideal by consuming real resources, principally the time of skilled workers, such as lawyers and judges. Those costs, often called litigation costs, are 'direct costs'. In addition, no legal system is perfectly accurate. Errors cause the legal system to fall short of achieving the goals of the substantive law (KLERMAN, 2015, p. 3-4).

O processo será considerado economicamente eficiente se reduzir ao máximo a soma entre os custos do procedimento e os custos do erro, conforme explica Daniel M. Klerman (2015, p. 3):

The key insight of the economic analysis of procedure is that optimal procedure requires minimization of the sum of direct costs and error costs (Posner 1973). Direct costs are attorney fees and other litigation expenses, and error costs are inefficient behavior resulting from inaccurate adjudication. While other approaches to procedure consider a welter of incommensurable values, such as fairness, cost, accuracy, speed, dignity, and participation (FRCP 2014, Mashaw 1976, Michelman 1973), the economic approach can analyze most procedural issues with just two terms direct costs and error costs. In addition, those two terms can, at least in principle, be measured empirically and expressed in money or as components of a social welfare function. While a benefit of economic analysis is that it provides an overarching framework for tradeoffs among many traditional factors - such as cost, accuracy, and speed - a potential criticism is that it tends to ignore other values, such as dignity and participation.

Anote-se que essa ideia de troca entre custos e acuidade no julgamento é bastante familiar no sistema processual brasileiro - ainda que não analisada sob esse viés. A imposição de prazos para a prática de atos processuais é um exemplo, bem como a citação ficta, as regras de distribuição do ônus probatório, a revelia, o princípio dispositivo (ainda que bastante mitigado atualmente na realidade brasileira), dentre outros. Todos trazem em si a ideia de escolha do legislador entre a acuidade do julgamento (prejudicada nos exemplos citados) e os custos do procedimento. 
A troca entre custos do procedimento e custos do erro judicial pode ser demonstrada por meio do seguinte gráfico:

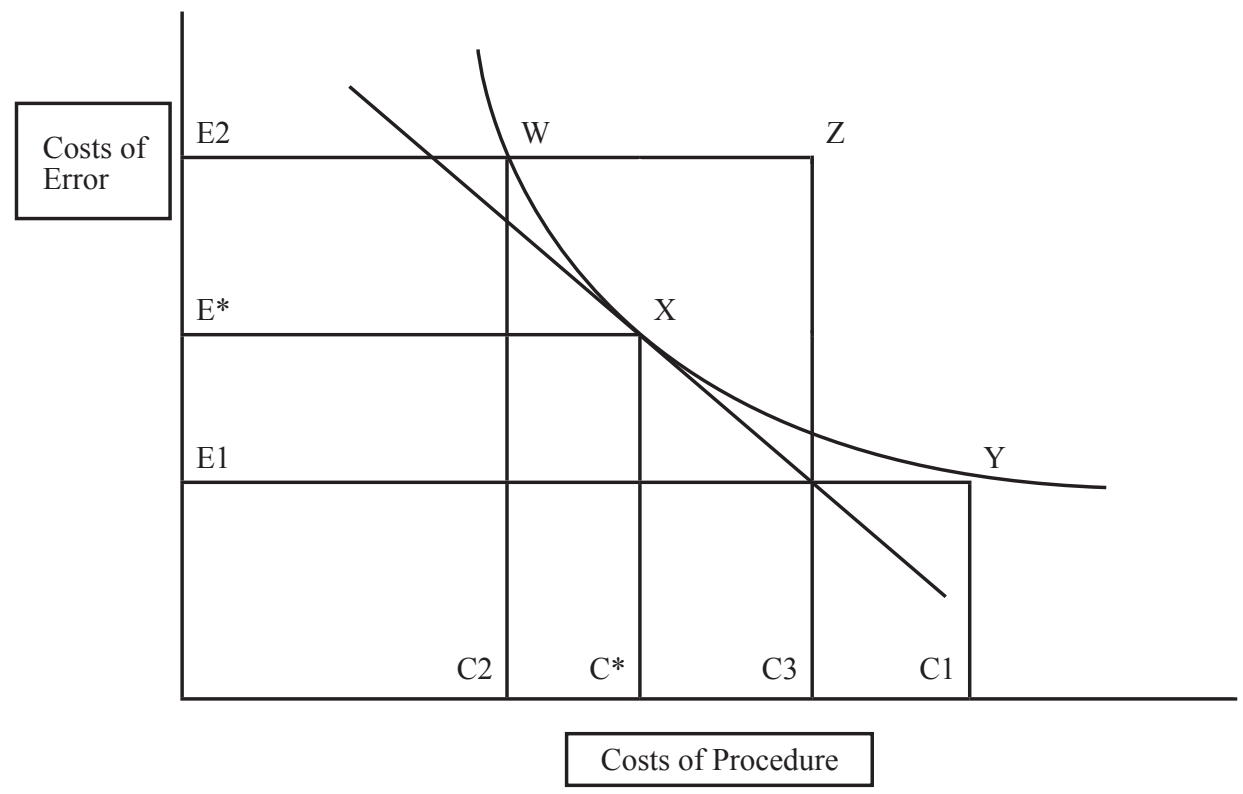

O gráfico assume que há uma diminuição gradual do benefício marginal do dispêndio de custos, ou seja, na medida em que o procedimento se torna mais elaborado, o benefício marginal em termos de diminuição do erro diminui.

O ponto de maior eficiência é "X", que minimiza a soma entre os custos do procedimento e os custos do erro; a máxima eficiência é alcançada, portanto, a um custo do procedimento "C", implicando em um custo de erro "E". Seria possível adotar um sistema que reduzisse ainda mais o custo do erro, como, por exemplo, no ponto "Y" do gráfico; mas ainda que no ponto "Y" se atinja um nível de "justiça substancial" mais elevado (uma vez que o custo do erro cai do nível " $\mathrm{E}$ " para " $\mathrm{E}$ "), isso ocorre a um custo mais elevado (de "C" para " $\mathrm{C}$ "').

\section{A Análise Econômica da Prova}

Assim como na análise econômica do processo, a análise econômica das normas e procedimentos atinentes à produção da prova no processo se concentrará na equação de troca entre os custos necessários à produção da prova e os respectivos benefícios, entendidos como a completude das informações constantes dos autos e a redução da possibilidade de existência de erro no julgamento. 
É intuitivo que a produção da prova traz efeitos benéficos ao processo, em razão da maior acuidade que permite ao julgamento, melhor embasado com a demonstração precisa dos fatos que subjazem à lide. Por outro lado, a produção da prova consome custos e tempo (que poderia ser também equacionado como custo), não sendo producente estendê-la ao infinito.

O objetivo deste estudo é analisar a relação entre os custos e os benefícios, a fim de indicar um ponto de equilíbrio em que a produção das provas seja considerada eficiente. Ou, conforme análise de Robert G. Bone (2003, p. 203), identificar quando os custos da produção de prova excedem os seus benefícios:

The purpose of formal discovery is to force reluctant opponents to disclose information and evidence relevant to a case. The standard rationale assumes that the parties, the judicial system, and the society at large all benefit from disclosure. The parties benefit because discovery makes it possible to litigate cases more fully and obtain more accurate results and because it reduces informational asymmetry and makes settlement easier do reach. The judicial system benefits by producing more accurate decisions and better settlement with a more complete factual record, and by saving litigation costs with a higher settlement rate. And society benefits by realizing deterrence gains from greater outcome accuracy and reduced process costs with a higher settlement rate.

At the same time, discovery generates costs at its own; not only the costs of promulgating and responding to discovery requests, but also the administrative costs of judicially resolving discovery disputes and the strategic costs associated with parties using discovery for purposes other than legitimate fact-finding. From an economic perspective, the case for formal discovery depends on whether the benefits exceed the costs.

\subsection{Os benefícios da produção da prova no processo}

Desnecessários grandes esforços para se compreender que a melhor produção de provas gera efeitos positivos ao processo, seja em relação aos litigantes, seja em relação à sociedade como um todo. Uma melhor apreensão da realidade dos fatos que jazem ao fundo de qualquer processo permite uma melhor qualidade no julgamento.

A qualidade do julgamento, ou, em outras palavras, a diminuição do erro, possibilita o pleno atendimento aos escopos da jurisdição - atende ao escopo social, ao efetivamente entregar às partes o resultado previsto abstratamente pela legislação e ao 
corretamente educar e conscientizar a sociedade acerca de seus direitos e obrigações; atende ao escopo jurídico, ao atuar de forma escorreita a vontade concreta da lei.

Sob o ponto de vista da Economia, uma melhor apuração dos fatos no processo judicial melhora a acuidade da decisão e, por isso, aumenta na sociedade o efeito dissuasório da prática do ilícito:

More accurate factfinding increases deterrence of wrongful conduct, which in turn reduces the number of cases and hence the aggregate costs of the legal process.

(...) The more accurate the process of determining guilt is, the less random punishment will be, and so the greater will be the law's deterrent effect. To put this point differently, greater accuracy in the determination of guilt increases the returns to being innocent (POSNER, 1999, p. 8).

A acuidade da resposta judicial traz para a sociedade a percepção de que condutas ilícitas serão adequadamente punidas pelo Poder Judiciário - quanto menos aleatória for a resposta judicial, melhor o efeito dissuasório sobre a sociedade. Essa conclusão fica evidente no exemplo extremado citado por Geoffrey P. Miller acima, em que o juiz simplesmente joga uma moeda para decidir sobre a condenação; nessa hipótese, em que a decisão é completamente aleatória, não há incentivo à parte para ser inocente (sendo inocente ou culpada, as chances de condenação seriam de 50\%).

Nas palavras de Richard Posner (1999, p. 9), o efeito dissuasório tem importância central na análise econômica da prova, uma vez que ele conecta a acuidade com a criação de incentivos para a conduta eficiente dos indivíduos:

Deterrence plays a starring role in the economic analysis of evidence because it links the concern with accuracy that is so central to the evidentiary process with the economist's conception of law as a system for creating incentives for efficient conduct. Since the accurate determination of facts at trial is important to the efficacy of law in imparting efficient incentives, accuracy in adjudication is an economic as well as moral and political value.

O erro no julgamento, portanto, cria custos sociais indesejáveis. A análise acerca do custo do erro já foi feita por diversos economistas ou adeptos da AED, em diversas áreas jurídicas. É comum a análise em se tratando de responsabilidade civil, por exemplo, quando se analisa o impacto do erro de julgamento sobre o dispêndio de valores na precaução de acidentes:

For example, economic analysis argues that the purpose of tort law is the minimization of the sum of precaution, accident, and administrative costs. When the legal system makes errors in tort cases (for example, failing to impose liability on negligent actors), the result is likely to be 
suboptimal expenditures on precautions and an excessive number of accidents. Similarly, errors in contractual adjudication are likely to result in inefficient effort by contracting parties who anticipate that the legal system will not sanction inadequate effort. Accidents caused by failure to take efficient precautions and the deviation from efficient contractual effort are 'error costs,' and, in principle, they can be measured in monetary or social welfare terms (KLERMAN, 2015, p. 4).

Erros de julgamento podem advir de 3 (três) tipos de erro: falsos negativos; falsos positivos; ou erro no cálculo dos danos. Os "falsos negativos" são falhas na imposição de responsabilidade quando seria apropriado e o seu efeito é reduzir o efeito dissuasório da jurisdição. Os "falsos positivos" são a imposição da responsabilidade em casos onde ela não era adequada - os "falsos positivos", em determinadas situações, podem funcionar como uma taxação extra a determinadas atividades (que em razão de circunstâncias de fato estão mais sujeitas aos erros) e causar reduções no exercício de atividades econômicas (essa redução na atividade econômica em razão de "falsos positivos" foi chamada "chilling costs"). Os erros de cálculo nos danos podem causar redução no efeito dissuasório da jurisdição ou redução da atividade econômica ("chilling effect”), quando forem sistematicamente muito baixos ou muito altos os cálculos.

Os apontamentos acima, especialmente os resultados sociais esperados a partir do erro de julgamento, consideram a jurisdição civil e principalmente os casos de responsabilidade civil. Análise similar pode ser feita em relação à jurisdição criminal, por exemplo, ao apontar como falsos positivos a condenação de um inocente e como falsos negativos a absolvição de uma pessoa culpada pelo delito. Tendo em vista que se entende mais danoso à sociedade a condenação de um inocente que a absolvição de um culpado, as regras do sistema processual tornam mais difícil a condenação, para evitar os "falsos positivos" (ainda que com aumento dos "falsos negativos"):

To see this point more clearly, consider a familiar example unrelated to pleading: the choice between a preponderanceof-the-evidence and a beyond-a-reasonable-doubt rule for the burden of persuasion in a criminal case. Neither rule is an easy choice on the basis of error rate alone. Compared to the preponderance standard, the beyond-a-reasonable-doubt standard reduces the number of erroneous convictions, but it also increases the number of erroneous acquittals. The choice between the two rules depends on the relative magnitude of these effects, but it also depends - and more important in this case - on how one assesses the social cost of erroneous convictions relative to erroneous acquittals. The selection of a beyond-a-reasonable-doubt standard for criminal cases reflects a judgment that the cost of erroneous 
convictions - the potential deprivation of liberty - is much greater than the cost of erroneous acquittals. As the familiar saying goes, it is better to acquit ten guilty men than convict an innocent one (BONE, 2003, p. 130-131).

Richard Posner (1999, p. 8) apresenta um modelo simplificado acerca da relação entre a qualidade da produção da prova e a dissuasão provocada pela acuidade do julgamento:

To see how accuracy in factfinding relates to deterrence, notice that the expected cost of punishment (EC) is actually the difference between the expected cost of punishment if one commits a crime $\left(\mathrm{EC}_{\mathrm{g}}=\mathrm{p}_{\mathrm{g}} \mathrm{S}\right.$, where $\mathrm{p}_{\mathrm{g}}$ is the probability of punishment if the accused is guilty and $\mathrm{S}$ is the sentence) and the expected cost of punishment if one does not commit a crime $\left(E C_{i}=p_{i} S\right.$ where $p_{i}$ is the probability of punishment if the accused is guilty [not guilty] ${ }^{6}$ and $\mathrm{S}$ is as before). Hence $\mathrm{EC}=\mathrm{p}_{\mathrm{g}} \mathrm{S}-\mathrm{p}_{\mathrm{i}} \mathrm{S}$; equivalently, $\mathrm{EC}=\left(\mathrm{p}_{\mathrm{g}}-\mathrm{p}_{\mathrm{i}}\right) \mathrm{S}$, making it transparent that if punishment is imposed randomly, so that the probability of punishment is the same regardless of guilt (that is, if $\mathrm{p}_{\mathrm{g}}=\mathrm{p}_{\mathrm{i}}$ ), the expected punishment cost for committing the crime will be zero. The more accurate the process of determining guilt is, the less random punishment will be, and so the greater will be the law's deterrent effect.

Os custos de eventual erro judicial são preponderantes para a existência de diferentes regras processuais acerca da presunção de veracidade das alegações da parte contrária - em casos criminais, assim como em casos em que "o litígio versar sobre direitos indisponíveis" (art. 345, II, do Código de Processo Civil), a revelia do réu não afasta a necessidade de produção probatória.

As considerações acima demonstraram que as partes e a sociedade em geral se beneficiam da melhor produção probatória em processos judiciais. No entanto, a produção de provas gera tempo e outros custos diretos, de forma que não é possível, como explicado acima, permitir de forma ilimitada a produção de provas.

A questão crucial para a AED é entender qual o modelo eficiente que equilibre a produção das provas e os custos incorridos.

\footnotetext{
6 No original o autor utiliza a expressão "guilty", mas, tendo em vista que a equação se refere ao custo esperado de punição no caso de o agente não cometer um crime, para que o modelo faça sentido o termo " $\mathrm{p}_{\mathrm{i}}$ " deve representar a probabilidade de punição para a hipótese de o acusado não ser culpado.
} 


\subsection{O modelo de eficiência na produção da prova}

Conforme apontado acima quando se tratou da análise econômica do processo e do equilíbrio entre custos do litígio e os custos do erro judicial, também para a produção da prova podemos afirmar que há uma diminuição gradual do benefício marginal do dispêndio de recursos, ou seja, na medida em que o procedimento se torna mais elaborado, o benefício marginal em termos de diminuição do erro diminui.

Para explicar a afirmação acima, imagine-se a produção probatória em um processo qualquer. Partindo-se da inexistência de qualquer prova produzida nos autos, o efeito benéfico da produção de uma primeira prova (uma testemunha ouvida, por exemplo) será imenso para a correta apreensão dos fatos; já a segunda prova, apesar de também benéfica, tem um efeito menos impactante que a primeira (o benefício marginal diminui); a terceira prova e as demais trazem benefícios cada vez menores.

Considerando que a produção de cada uma das provas acarrete determinado custo (e considerando-se que este custo mantém-se estável ou evolui de forma crescente), em certo ponto o custo na produção da prova excederá o seu benefício.

Para encontrar um modelo eficiente de produção de provas, os economistas concluirão que a produção de provas deverá ser levada até o ponto em que o custo marginal da produção probatória se iguala ao benefício marginal alcançado:

In words, the search should be carried to the point at which marginal cost and marginal benefit are equated. The amount of evidence at the optimum point will be greater the higher the stakes in the case, the lower the cost of obtaining evidence, and the greater the effect of evidence in increasing the likelihood of an accurate outcome (POSNER, 1999, p. $6)$.

Richard Posner (1999, p. 5-6) nos traz um modelo de eficiência na produção da prova:

The search process, which in the litigation setting is the process of obtaining, sifting, marshaling, presenting, and (for the trier of fact) weighing evidence, confers benefits and incurs costs. (Social and private benefits and costs must be distinguished, but that is for later.) Benefits are a positive function of the probability ( $p$ ) that if the evidence is considered by the trier of fact the case will be decided correctly, and of the stakes (S) in the case. To keep things simple, I shall assume that the benefits are simply the product of the two terms, hence $\mathrm{pS}$, where $\mathrm{p}$ is a positive function of the amount of evidence (x), so that the full expression for the benefits of the search is $\mathrm{p}(\mathrm{x}) \mathrm{S}$. With enough evidence, $\mathrm{p}$ might equal 1 , meaning that a trial would be certain to 
produce the correct outcome. The costs of the trial (c) are also a positive function of the amount of evidence (x).

Some of these assumptions will have to be relaxed later, but for now, the net benefits $(\mathrm{B}(\mathrm{x}))$ of what I am calling the 'evidence search' in a case are given by

(1) $\mathrm{B}(\mathrm{x})=\mathrm{p}(\mathrm{x}) \mathrm{S}-\mathrm{c}(\mathrm{x})$

and thus the optimum amount of search - the amount that maximizes net benefits - satisfies

(2) $\mathrm{p}_{\mathrm{x}} \mathrm{S}=\mathrm{c}_{\mathrm{x}}$

where subscripts denote derivatives.

(...)

For this optimum to exist, it is enough if $\mathrm{p}(\mathrm{x})$ is increasing at a decreasing rate $\left(\mathrm{p}_{\mathrm{xx}}<0\right)$ and that $\mathrm{c}_{\mathrm{x}}$ is nondecreasing $\left(c_{x x} \geq 0\right)$.

O modelo confirma a afirmação acima de que a quantidade eficiente de produção de provas é encontrada quando o custo marginal da produção probatória se iguala ao benefício marginal alcançado. Importante notar que o valor da demanda e o custo na obtenção da prova têm papel determinante na constatação do equilíbrio.

Quanto maior o valor da demanda, maior o benefício de uma melhor apuração dos fatos (uma vez que, segundo o modelo, o benefício se obtém a partir da multiplicação da probabilidade da prova em influenciar o resultado e o valor da demanda). Assim, quanto maior o valor da demanda, mais provas serão coletadas até se alcançar o nível ótimo na produção.

Por outro lado, o custo na obtenção da prova é fator determinante para se encontrar o ponto de equilíbrio. Quando menor for o custo de obtenção da prova, maior será a quantidade de provas amealhadas até se alcançar o nível ótimo na produção.

Anote-se que a ideia de custo empregada pela AED não deve se restringir aos custos diretos e unicamente monetários da produção da prova. Podem também ser incluídos nesse lado da equação outros custos indiretos advindos dos efeitos sociais do processo de produção de provas. ${ }^{7}$

A partir dessas constatações, podemos tentar analisar, dentro das regras de produção probatória adotadas em determinado sistema processual, aquelas que estão de acordo com o modelo eficiente de produção de provas, ou seja, que limitam a produção de

\footnotetext{
7 "Costs may seem too narrow a concept to serve as a criterion to choosing among alternative rules of evidence. However, this objection may rest in too narrow a concept of 'costs'. The costs of evidence search, in a proper economic analysis, are not limited to time and other direct costs. They include indirect costs resulting from the incentive effects of search process" (POSNER, 1999, p. 10).
} 
provas cujos custos superem os benefícios ou que impliquem em diminuição de custos no processo de se amealhar evidências.

Richard Posner (1999, p. 50) aponta algumas das regras no sistema norteamericano (especialmente das "Federal Rules of Evidence") em que a racionalidade econômica acima delineada se mostra presente:

For example, Rule 201, involving judicial notice of incontestable facts (that is, no evidence is required to prove the obvious), is important, but it is obviously sound as a matter of economics as well as common sense: evidence of what is obvious would involve some cost and yield no benefit.

A dispensa da produção de provas acerca de fatos incontroversos é também prevista no sistema brasileiro (art. 374 e incisos do Código de Processo Civil ${ }^{8}$ ) e traz em si a inteligência econômica acerca da utilidade da produção da prova: inexistindo benefício (uma vez que o fato é incontroverso e a prova não poderá modificar essa constatação), não é eficiente despender recursos com a produção da prova.

\section{Ainda segundo Richard Posner (1999, p. 56-57):}

The Federal Rules of Evidence define relevance as 'having any tendency to make the existence of any fact that is of consequence to the determination of the action more probable or less probable than it would be without the evidence' (Rule 401). The rules make relevant evidence admissible and irrelevant evidence inadmissible (Rule 402), but relevant evidence may be excluded if its probative value is substantially outweighed by the danger of unfair prejudice, confusion of the issues, or misleading the jury, or by considerations of undue delay, waste of time, or needless presentation of cumulative evidence' (Rule 403). These rules make economic sense. In Bayesian terms (and well illustrating the heuristic value of Bayes' theorem for understanding the law of evidence), evidence is relevant if its likelihood ratio is different from 1 and irrelevant if it is 1. Irrelevant evidence so defined has zero social benefits, though it may confer a private benefit by confusing or prejudicing the jury. (...)

\footnotetext{
"Art. 374. Não dependem de prova os fatos:

I - notórios;

II - afirmados por uma parte e confessados pela parte contrária;

III - admitidos no processo como incontroversos;

IV - em cujo favor milita presunção legal de existência ou de veracidade".
} 
Rule 403, in requiring an explicit comparison of benefit and cost, is central to an economic analysis of the law of evidence in much the same way that the Hand formula is central to the economic analysis of the law of torts. It sets forth a cost-benefit formula for deciding the most common question in the law of evidence, which is whether to admit or exclude evidence. It bears the same relation to Equation (4) $\left(-p_{x} S=c_{x}\right)$, the economic formula for the optimal amount of evidence, as the Hand formula does to the economic formula for the optimal amount of care $\left(-\mathrm{p}_{\mathrm{x}} \mathrm{L}=\mathrm{c}_{\mathrm{x}}\right)$.

A regra de admissibilidade unicamente das provas ditas "relevantes", prevista no sistema norte-americano, também tem similaridade com o sistema brasileiro, o qual determina que o juiz indefira diligências inúteis (ou seja, sem relevância para a melhor apreensão dos fatos relativos à causa) ou meramente protelatórias (art. 370, parágrafo único, do Código de Processo $\mathrm{Civil}^{9}$ ).

Ainda segundo a regra do sistema norte-americano acima apresentada, mesmo as provas que poderiam ser consideradas relevantes para a melhor apreensão dos fatos inerentes à demanda, devem ser rejeitadas na hipótese de seu benefício ser superado pelo risco de causar possível prejuízo ou em consideração à perda de tempo ou ao acúmulo de evidências despropositado.

Na opinião de Richard Posner, a regra faz sentido dentro de uma análise econômica e diante dos modelos acima dispostos.

No sistema processual brasileiro, regras com a mesma racionalidade econômica podem ser encontradas. Veja-se que a regra que impede a utilização de provas ilícitas ou moralmente ilegítimas (arts. 369 do Código de Processo Civil ${ }^{10}$ e $5^{\text {o }}$, LVI, da Constituição Federal ${ }^{11}$ ) traz em si a ideia de comparação dentre os custos da produção da prova (incluindo-se os custos sociais, entendidos como os incentivos ao comportamento dos indivíduos) e os seus benefícios. ${ }^{12}$

\footnotetext{
9 “Art. 370. Caberá ao juiz, de ofício ou a requerimento da parte, determinar as provas necessárias ao julgamento do mérito.

Parágrafo único. O juiz indeferirá, em decisão fundamentada, as diligências inúteis ou meramente protelatórias".

10 "Art. 369. As partes têm o direito de empregar todos os meios legais, bem como os moralmente legítimos, ainda que não especificados neste Código, para provar a verdade dos fatos em que se funda o pedido ou a defesa e influir eficazmente na convicção do juiz".

11 Art. 5, LVI: "são inadmissíveis, no processo, as provas obtidas por meios ilícitos".

12 No que diz respeito às provas ilícitas, a doutrina, com certa tranquilidade, entende cabível a sua apreciação nas hipóteses em que a prova seja útil à demonstração da inocência do acusado e sirva, portanto, à defesa. A hipótese apenas reforça a racionalidade econômica da regra, ponderando-se os benefícios obtidos com a produção da prova com os seus custos.
} 
Também a ideia de limitação da produção de provas repetitivas está presente nos arts. 357, $\S 6^{\circ}, 443$ e 464, $\S 1^{\circ}$, do Código de Processo Civil ${ }^{13}$ e no art. 34 da Lei n. 9.099. ${ }^{14}$

Feitas as considerações acima, depreende-se que existe um limite racional à produção das provas no processo, imposto pelos custos - diretos e indiretos - de sua produção. Ainda que a melhor e mais ampla produção de provas possa ser benéfica à melhor acuidade da prestação jurisdicional, este benefício deve ser sopesado com os custos correlatos, a fim de não se causar um mal maior que o bem perseguido.

Diante destas conclusões, pode-se analisar à luz da AED a limitação à produção probatória existente no sistema dos juizados especiais, a fim de verificar a sua racionalidade econômica e os resultados esperados a partir de sua adoção.

\section{O Juizado Especial Cível e a limitação à produção probatória}

A Lei n. 9.099/95 instituiu os juizados especiais cíveis, microssistema processual com competência para "processo e julgamento das causas cíveis de menor complexidade" (art. 30, caput), entendidas especialmente como aquelas "cujo valor não exceda a quarenta vezes o salário mínimo" (art. $\left.3^{\circ}, \mathrm{I}\right)$.

A lei criou um procedimento sobremaneira simplificado e, em princípio, pouco dispendioso - o processo nos juizados especiais "orientar-se-á pelos critérios da oralidade, simplicidade, informalidade, economia processual e celeridade" (art. $2^{\circ}$ ). Há limitações procedimentais em relação ao processo comum (como a impossibilidade de intervenção de terceiros e a restrição à interposição de recursos), inclusive e especialmente em relação à produção de provas.

Todas as provas devem ser produzidas durante a audiência de instrução (art. 33); as partes podem arrolar no máximo 3 (três) testemunhas (art. 34) e é vedada a produção de prova pericial, sendo possível unicamente a realização de prova técnica

13 “Art. $357, \S 6^{\circ} . \mathrm{O}$ número de testemunhas arroladas não pode ser superior a 10 (dez), sendo 3 (três), no máximo, para a prova de cada fato".

"Art. 443. O juiz indeferirá a inquirição de testemunhas sobre fatos:

I - já provados por documento ou confissão da parte;

II - que só por documento ou por exame pericial puderem ser provados".

“Artigo 464, § 1": “O juiz indeferirá a perícia quando:

I - a prova do fato não depender de conhecimento especial de técnico;

II - for desnecessária em vista de outras provas produzidas;

III - a verificação for impraticável".

14 “Art. 34. As testemunhas, até o máximo de três para cada parte, comparecerão à audiência de instrução e julgamento levadas pela parte que as tenha arrolado, independentemente de intimação, ou mediante esta, se assim for requerido". 
simplificada, nos termos do art. 35, mediante a inquirição de técnicos da confiança do juiz ou a inspeção de pessoas ou coisas.

Há uma clara racionalidade econômica na limitação da produção de provas nos juizados especiais, a qual pode ser explicada pelo modelo de produção eficiente de provas desenvolvido por Richard Posner e acima descrito.

Vimos que, à luz de um modelo econômico de eficiência, a produção de provas deverá ser levada até o ponto em que o custo marginal da produção probatória se iguala ao benefício marginal alcançado. O benefício marginal, por sua vez, mede-se pela probabilidade de a evidência ser considerada pelo julgador para julgar de forma correta a demanda, multiplicada pelo valor da demanda.

Ou seja, nas palavras do próprio Richard Posner (1999, p. 6), "the amount of evidence at the optimum point will be greater the higher the stakes in the case, the lower the costs of obtaining evidence, and the greater the effect of evidence in increasing the likelihood of an accurate outcome".

Ao admitir que processos com valores reduzidos (menos de 40 salários mínimos) sejam submetidos a um procedimento que limite a produção de provas (e, por isso, tenha maior probabilidade de incorrer em erros de julgamento), o legislador demonstra entender que os custos do erro judicial em tais casos são menores que os custos necessários para se obter um maior acerto nas decisões.

Importante não perder de vista que os custos, tanto do procedimento quanto do erro judicial, não se limitam unicamente aos custos impostos às partes litigantes ou ao valor monetário em jogo. Algumas demandas, ainda que tenham um valor monetário reduzido, podem tratar de interesses mais caros à sociedade e que, portanto, imponham um custo mais elevado em caso de erro no julgamento.

Justamente por isso as demandas que tenham natureza alimentar, falimentar, fiscal ou que sejam de interesse da Fazenda Pública, bem como as relativas a acidentes de trabalho, a resíduos e ao estado e capacidade das pessoas, ainda que de cunho patrimonial, estão excluídas da competência do JEC (art. $3^{\circ}, \S 2^{\circ}$, da Lei n. 9.099/95).

Conclui-se das análises acima que o legislador optou claramente por diminuir os custos do procedimento nos processos submetidos ao JEC, e por isso impedir a produção de determinadas provas, ainda que a custo de um aumento possível e provável na ocorrência de falhas no julgamento da demanda.

Ressalte-se que a leitura do art. $3^{\circ}$, caput e inciso I, da Lei n. 9.099/95, deixa claro que o legislador expressamente optou por considerar dentre as causas de "menor complexidade", cuja competência para julgamento será do JEC, aquelas "cujo valor não exceda a quarenta vezes o salário-mínimo", sem qualquer consideração acerca da complexidade probatória em concreto. 
A intenção do legislador e a eficiência econômica do sistema, no entanto, não parecem haver sido inteiramente compreendidas pelos operadores do sistema dos juizados especiais. Com tranquila maioria, tem-se entendido que a complexidade da matéria probatória e a análise subjetiva do juiz acerca da necessidade de produção de determinada prova não admitida pelo procedimento acarretam na incompetência do JEC para apreciação da demanda.

Conforme lição de Ricardo Cunha Chimenti (2012, p. 88):

As questões de direito, por mais intrincadas e difíceis que sejam, podem ser resolvidas dentro do Sistema dos Juizados Especiais, o qual é sempre coordenado por um juiz togado.

(...)

Por outro lado, quando a solução do litígio envolve questões de fato que realmente exijam a realização de intrincada prova, após a tentativa de conciliação o processo deve ser extinto e as partes encaminhadas para a Justiça ordinária. É a real complexidade probatória que afasta a competência dos Juizados Especiais.

Maria do Carmo Honório (2017, p. 22) manifesta opinião idêntica:

Se a solução da questão jurídica depender da produção de intrincada prova pericial, mesmo que o valor da causa não ultrapasse o limite de alçada, haverá incompatibilidade com o procedimento do Juizado Especial, calcado na oralidade e todas as suas derivações.

Não se pode deixar de observar ainda o princípio constitucional da ampla defesa, que garante ao réu o direito de provar o fato desconstitutivo do direito do autor, de tal forma que, se isso só for possível com perícia, inevitável será o reconhecimento da incompetência do juízo.

Esse entendimento se encontra consolidado no Poder Judiciário, conforme se depreende do enunciado 54 do Fórum Nacional de Juizados Especiais ("FONAJE"): "A menor complexidade da causa para a fixação da competência é aferida pelo objeto da prova e não em face do direito material".

Pela interpretação a contrario sensu da ementa do acórdão prolatado no recurso extraordinário 571.572-8, relatado pelo Ministro Gilmar Mendes (BRASIL, 2008), nota-se que o Supremo Tribunal Federal também entendeu que a complexidade da causa para fins de verificação da competência dos juizados especiais se afere pela efetiva complexidade da matéria probatória:

Em se tratando de demanda que se resolve pela análise de matéria exclusivamente de direito, a dispensar instrução complexa, cabível seu processamento no Juizado Especial. 
O entendimento esposado acima, além de estar em confronto com a simples leitura do art. $3^{\circ}$, I, da Lei n. 9.099/95, quebra com a eficiência econômica buscada pelo sistema instituído pela Lei n. 9.099/95.

Em sentido contrário, o Superior Tribunal de Justiça, no julgamento da Medida Cautelar n. 15.465, relatado pela Ministra Nancy Andrighi (BRASIL, 2009), expressamente afirmou que a competência dos juizados especiais não se relaciona à complexidade da matéria probatória (ou à "necessidade ou não de perícia"):

Não há dispositivo na Lei n. 9.099/95 que permita inferir que a complexidade da causa - e, por conseguinte, a competência do Juizado Especial Cível - esteja relacionada à necessidade ou não de perícia.

(...)

Ao regulamentar a competência conferida aos Juizados Especiais pelo art. 98, I, da CF, a Lei n. 9.099/95 fez uso de dois critérios distintos - quantitativo e qualitativo - para definir o que são 'causas cíveis de menor complexidade'. A menor complexidade que confere competência aos Juizados Especiais é, de regra, definida pelo valor econômico da pretensão ou pela matéria envolvida. Exige-se, pois, a presença de apenas um desses requisitos e não a sua cumulação. (BRASIL, 2009).

Por absolutamente pertinente à discussão ora encetada, copia-se trecho do voto vencedor da Ministra relatora:

No julgamento do CC 83.130/ES, de minha relatoria, DJ de 04.10.2007, a $2^{\text {a }}$ Seção decidiu que 'a Lei $n$. 10.259/2001 [Juizados Especiais Federais] não exclui de sua competência as disputas que envolvam exame pericial'. Naquela ocasião, consignei que 'o critério adotado para a fixação da competência foi razoavelmente objetivo, incluindo as causas de competência da Justiça Federal até o valor de sessenta salários mínimos', concluindo que 'excluir pura e expressamente os litígios que envolvam perícia contraria a mens legis, bem como a interpretação mais adequada à hipótese'.

O raciocínio supra se aplica perfeitamente aos Juizados Especiais regidos pela Lei n. 9.099/95, que, assim como os Juizados Especiais Federais, atendem ao preceito insculpido no art. 98, I, da CF.

A conclusão adotada pela Ministra Nancy Andrighi no julgamento apontado está em consonância com a intenção do legislador ao instituir os juizados especiais e, conforme acima demonstrado, encontra-se em sintonia com a ideia de eficiência na produção da prova desenvolvida a partir das concepções da AED. 
Conclusões

Conforme afirmado no capítulo introdutório, o presente estudo não tem por finalidade desenvolver um modelo econômico completo de análise da eficiência na produção da prova no processo civil, ou apontar respostas definitivas para a questão proposta.

Pretende-se unicamente apresentar de forma simples e sumária a forma de apreciação de determinadas questões processuais à luz da AED, por meio da utilização de conceitos da ciência econômica - os quais, conforme esclareceu Fábio Nusdeo, são familiares a qualquer pessoa e decorrentes da avaliação lógica de situações cotidianas.

Diante do modelo proposto de eficiência na produção da prova, constatase que existe uma clara inteligência econômica na limitação dos meios probatórios nos processos submetidos ao JEC, a qual deve ser imposta independentemente da apreciação subjetiva do magistrado acerca da utilidade na produção de determinada prova não admitida pelo procedimento (a prova pericial é o exemplo clássico).

O maior risco de erro de julgamento em decorrência da falha na apreensão dos fatos subjacentes é natural diante do tradeoff entre os custos do procedimento e do erro judicial, tendo o legislador feito claramente a sua escolha no que diz respeito àquelas causas que encerram valores monetários mais acanhados (até quarenta salários-mínimos) e não envolvam outros valores não monetários caros à sociedade.

São Paulo, março de 2018.

Referências

BONE, Robert G. Civil procedure: the economics of civil procedure. New York: Thomson, 2003.

BRASIL. Superior Tribunal de Justiça (3. Turma). Medida Cautelar n. 15.465-SC. Relatora: Ministra Nancy Andrighi. Brasília, DF, 28 de abril de 2009. Disponível em: <https://ww2.stj.jus.br/ processo/revista/inteiroteor/?num_registro $=200900653243 \& d t \_p u b l i c a c a o=03 / 09 / 2009>$. Acesso em: 6 mar. 2018.

BRASIL. Supremo Tribunal Federal (Tribunal Pleno). Recurso Extraordinário n. 571.572-8-BA. Relator: Ministro Gilmar Mendes. Brasília, DF, 8 de outubro de 2008. Disponível em: $<$ http://redir. stf.jus.br/paginadorpub/paginador.jsp?docTP=AC\&docID=576021>. Acesso em: 6 mar. 2018.

CHIMENTI, Ricardo Cunha. Teoria e prática dos juizados especiais cíveis estaduais e federais. 13. ed. São Paulo: Saraiva, 2012.

HONÓRIO, Maria do Carmo; STEINBERG, José Fernando. Manual dos juizados especiais cíveis \& da fazenda pública: com comentários sobre os enunciados do Fonaje. Curitiba: Juruá, 2017. 
KLERMAN, Daniel M. The economics of civil procedure. University of Southern California Law School: Legal Studies Working Paper Series, paper 151, 2015. Disponível em: $<$ http://law.bepress. com/usclwps-lss/151>. Acesso em: 6 mar. 2018.

MANKIW, N. Gregory. Introdução à economia. Tradução de Allan Vidigal Hastings. Tradução da 3. ed. Norte-Americana. São Paulo: Thomson, 2007.

MILLER, Geoffrey P. The legal-economic analysis of comparative civil procedure. American Journal of Comparative Law, Oxford, v. 45, n. 4, p. 905-918, Oct. 1997.

NUSDEO, Fábio. Curso de economia: introdução ao direito econômico. 7. ed. rev. atual. e ampl. São Paulo: Revista dos Tribunais, 2013.

POSNER, Richard A. An economic approach to the law of evidence. University of Chicago Law School, John M. Olin Law \& Economics Working Paper No. 66, February, 1999. Disponível em SSRN: $<$ https://papers.ssrn.com/sol3/papers.cfm?abstract_id=165176>. Acesso em: 6 mar. 2018.

SALAMA, Bruno et al. Análise econômica do direito nas decisões judiciais. In: CUEVA, RICARDO VILLAS BÔAS. (Coord.). Seminário teoria da decisão judicial. Brasília, DF: Coordenadoria de Serviços Gráficos do DCF, 2014. (Série Cadernos do CEJ; 30).

SANTOS, Boaventura de Sousa. Um discurso sobre as ciências. 5. ed. São Paulo: Cortez, 2008. 